\title{
The Research of School-enterprise Collaborative Education Platform Construction of Universities and Colleges under the Background of "Double First-Rate" Construction
}

\author{
Liang Xu \\ Office of Academic Affairs Hebei University of geosciences \\ Shijiazhuang, China \\ 136, Huaian East Street, Shijiazhuang
}

\begin{abstract}
Under the background of "Double First-Rate", the training of talents in advanced colleges and universities began to move towards a new stage. This article is mainly for the study of the training of applied talents, bringing out of the idea of the construction of School-enterprise collaborative education platform of advanced colleges and universities. The article mainly introduces the connotation and pattern of the cooperative education between schools and enterprises, as well as elaborates its necessity. Finally, the paper puts forward the realization mechanism and path of School-enterprise collaborative education platform, and puts forward some concrete and practical strategies, aiming at giving suggestions for the training of talents in advanced colleges and universities.
\end{abstract}

Keywords-Double First-Rate; Advanced colleges and universities; School-enterprise cooperation; Education platform

\section{INTRODUCTION}

In 2016, our country put forward the goal of building world-class first-rate universities and first-rate disciplines, which is the new requirement of advanced colleges and universities by national education development. Therefore, in the face of such "double first-rate" background requirements and in the conduct of personnel training, advanced colleges and universities must always meet the requirements of students' future development, training for the future development of the country and providing fresh blood and first-class talent. In addition, with the new requirements popular entrepreneurship and innovation, advanced colleges and universities must cooperate with enterprise. In this context, this paper carries on the related research to School-enterprise collaborative education and its platform construction.

\section{THE CONNOTATION AND MODE OF SCHOOL-ENTERPRISE}

\section{COLLABORATIVE EDUCATION}

\section{A. The connotation of School-enterprise collaborative} education

With the continuous development of education, the connotation of School-enterprise collaborative education is constantly enriched, and the connotation in the practice is more practical. From the literal point of view, the connotation of school-enterprise collaboration can be divided into two concepts of school-enterprise cooperation and collaboration. In general, school-enterprise cooperation mainly refers to that the school, in the actual teaching, and enterprises play their own advantages of resources to help students learn the theoretical knowledge and apply these knowledge into practice, combining learning and work better, so as to promote the overall teaching effect. Under the guidance of such ideas, China's education began to move to a new stage. Since 2012, the Ministry of Education has embarked on the implementation of the "Higher Education Innovation Enhancement Program". In this plan, it is proposed that we need to continue to break through the barriers between internal universities and outside mechanisms through collaborative innovation, thus breaking down and changing the current teaching situation. This paper argues that the implementation of School-enterprise coordinative education, based on the existing school-enterprise resources, is to complement each other and through the integration of resources, to train full-round talents. This is the future requirements to achieve quality education and new type talent [1].

\section{B. The mode of School-enterprise collaborative education}

The mode of cooperative education between schools and enterprises has been developing for a long time, especially in many developed countries, and it has been proved to have very 
good results in practice. Therefore, China in recent years has gradually begun to implement the School-enterprise collaborative education mode. This paper, after studying School-enterprise collaborative education mode from home and abroad, shows that the current collaborative mode of School-enterprise education is divided into the following categories. The first is School-enterprise cooperation schooling mode, which mainly refers to schools and enterprises to cooperate in schooling, with the government playing a macro-controlling role in helping schools and enterprises to develop appropriate rules and regulations. The second mode is school-led, business-support mode, in which the school is at the core position, and enterprises and governments are to be in support. Third is the order mode, which mainly refers to that the school not only signed a joint business agreement with the enterprise, but also signed Commissioned Labor Agreement [1] with students and parents when enrolling, so that forming a close relationship between the order units and students future internship employment. Fourth, the practice training mode. It mainly refers to that when students, after learning a certain amount of theoretical knowledge, and in accordance with the agreement between the school and the enterprise, will be internship in certain cooperation unit, applying the theoretical knowledge into practice and improving operation and practical skills. The last one is a more common mode, the produce-study-research mode. This model mainly refers to through their own scientific research advantages, schools help their cooperative enterprises to solve some of the problems in actual production and operation process. This mode can provide, on the one hand, new technology to enterprise, and on the other hand, financial support of enterprises to schools, so as to better promote scientific research and improve the level of education of student [2].

\section{THE NECESSITY TO BUILD A SCHOOL-ENTERPRISE}

\section{COOPERATION EDUCATION PLATFORM}

\section{A. The Need to Cultivate Applied Talents}

At present, the level of higher education in our country is gradually improving with the continuous development of education, especially the higher education, which has gradually moved towards the popular developing phase. Therefore, under such circumstances, one of the important duties of higher education is to cultivate talents for social and economic development needs. In particular, the cultivation of applied talents has become an important goal of higher education, because it is not only related to the employment of students, but also related to the future economic development. Therefore, in the training of applied talents, the traditional concept of running a school must be gradually abandoned, especially the traditional academic training mode. Although the study of students' theoretical knowledge also needs to be paid attention to, blindly pursuing the profound discipline, theoretical knowledge is not enough. The most important is to let students clearly understand the meaning of practice and effectively enhance the practical ability. At the same time, training the application of talent is, through the teaching mode of practice, developing students' systematic and rigorous training, and constantly strengthening their ability to work, which can effectively enhance the core competitiveness of personnel training.

\section{B. Ways to Increase the Practice of Teaching}

In order to achieve practical teaching, the school must, in the actual teaching, increase and widen the teaching approach. The implementation and construction of the school-enterprise collaborative education platform is one of the effective ways to achieve practical teaching, as well as playing a very important role in cultivating students' professional application ability. There are still many problems in the practice teaching of colleges and universities at present, such as the lack of clear standards in the practice teaching of most applied universities at present, because of which many schools, in the conduct of personnel training, did not be able to combine the professional characteristics and personnel training requirements, neither to make appropriate practice teaching standards. Even in practice, there is no clear syllabus and teaching plan so it is difficult to organize and assess the practice of specific content of teaching, methods, and the performance of teachers and students, which will greatly limit the practice of teaching effect.

\section{To Promote the Effective Mechanism of School-enterprise \\ Cooperation}

In addition, with the continuous development and deepening of the cooperation between schools and enterprises in our country, we should gradually establish an effective mechanism for the cooperation between schools and enterprises on the existing basis, so as to promote the long-term development of school-enterprise cooperation [3]. Therefore, the construction of school-enterprise collaborative education platform is a very good security mechanism. For schools, students can find certain cooperative unit and thus to be in relatively appropriate internships and employment units. And for enterprises, they can also hire high quality, stable potential talent. Therefore, the establishment of school-enterprise cooperative education platform for both are very important, must be taken seriously. For the school, it is necessary in the teaching to gradually change the school's original education and teaching concepts and help students more actively to be in enterprise cooperation and to effectively understand the standards and requirements of business users, so as to continuously improve the professional skills of students. For the enterprises, they should be the main receiving units of the graduates from applied universities and be clear of what kind of talents they need, and actively provide advice for schools, so as to help schools continuously cultivate excellent talents for social development. It is important to note that the idea of combining student theory with practice is necessary, and it is also a key point to develop the ability of solving practical problem as well as to train talents who are suitable for the need of enterprises [4].

\section{The REALIZATION MECHANISM AND PATH OF THE}

\section{COOPERATIVE EDUCATION PLATFORM}

In the current Double First-Rate background, colleges and universities and enterprises in the construction of school-enterprise collaborative education platform, can achieve the mechanism and path in various ways. No matter 
through what kind of mechanism and path, the ultimate goal is to promote tripartite common development of schools, students and enterprises. While it is necessary to strengthen students' practical skills and professional skills in practical practice, it is important to note that building a school-enterprise collaborative education platform is not just a simple practice for students to practice or intern but rather important to face the real problems of enterprises, to be aware of students' capacity and the needs of employment, so as to effectively build a close school-enterprise alliance and achieve cooperation between schools and enterprises, meeting the needs of personnel training to the greatest extent. Through the joint efforts of schools, enterprises and society, we will continue to build a collaborative education platform for the development of schools and enterprises.

\section{A. Realization Mechanism of School-enterprise}

\section{Collaborative Education Platform}

For school-enterprise collaborative education platform to really play a role in meeting the needs of personnel training, it is necessary to study the realization mechanism of platform construction in the process of building a platform for education, In particular, to get rid of the past situation of relying relationships to arrange students into enterprises, gradually abandoning the vicious circle of enterprises employment, and to achieve the unity of the needs of both enterprises and schools, so as to truly solve the problem of both sides [5]. Both schools and enterprises, in the collaborative education platform, can achieve the dual purpose of teaching and employing, and not only to promote the common progress of teaching and research, but also to achieve effective interaction between teachers and students, and ultimately achieve a win-win between schools and enterprises, promoting social and economic development.

\section{B. Implementation Path of School-enterprise Collaborative}

\section{Education Platform}

On the basis of establishing appropriate mechanism for School-enterprise collaborative education, schools and enterprises should work together to find an effective path to realize the platform of educational cooperation between schools and enterprises, for it is related to the common needs of both sides. In order to achieve the construction of the school-enterprise collaborative education platform under the background of Double First-Rate, this paper, in the light of the existing literature and actual teaching needs, finally put forward the following realization path.

First, schools and businesses can conduct exploratory teaching based on the same problem. This mainly refers to that enterprises can bring the actual problem in the production into the classroom through school and teachers, so that students can, under the guidance of teachers, analyze the problem and find a solution through theoretical knowledge of learning and data collection, thus ultimately applying the solution to actual production of enterprises. Second, teacher can introduce actual case and business projects of the enterprise into the classroom. Students can be guided to develop and design real products. In the process of participation, students can deeply acknowledge the real production process of the enterprise and the theoretical knowledge and technology needed, which can further improve their skills. Finally, teacher can lead student to the actual project. Schools and enterprises can cooperate to bring specific projects into school, so that teachers can lead students to choose the appropriate methods and techniques, and put forward effective solutions. Of course, in this process, teachers will choose some students whose professional skills is relatively strong to fully participate in the practice.

In addition, in the specific implementation path, there are many practical methods that schools and enterprises can effectively learn from. For example, the enterprise can publish some job requirements and recruitment information for students through school, so that students will understand what kind of requirements the actual work needs, which can help students enhance their ability in a specific way. Schools can also conduct a certain degree of pre-job training and training courses based on the needs of enterprises. Second, school can organize students into enterprises to practical work for a certain period of time, so that students can be clear of the actual requirements of enterprises, and apply their own theoretical knowledge into work, enhancing their work quality and efficiency. What's more, in the current national efforts to cultivate innovative talents, many colleges and universities are implementing university student innovation and entrepreneurship training program. The implementation of this project results in that many students learn theoretical knowledge well but also pay more attention to applying theoretical knowledge into actual innovation, which comprehensively improves their own innovation ability. Especially under the guidance of teachers, students can be more effective on the road of innovation and entrepreneurship.

Finally, after students' enrollment, schools need to continuously develop students' innovative consciousness and innovative thinking, especially, to guide students from the lower grades to understand their own major and career prospects, developing students' professional quality as well as enhancing students' sense of belonging to their major [6].

\section{CONCLUSION}

The construction of school-enterprise collaborative education platform is not only a new mode of higher personnel training but also an important way to improve the quality of higher education. In the process of platform construction, colleges and universities should take the economic development demand as the guide, take the enterprise development demand as the breakthrough point, according to local conditions, develop effective evaluation and incentive measures, Enterprises should use the scientific research strength of colleges and universities to carry out resource integration, promote industrial restructuring and optimization, finally make the two promote each other and common development.

\section{REFERENCES}

[1] Li Chenglong. A Study on School-enterprise Innovative Entrepreneurial Education Mechanism [J]. Chinese University Science and Technology .2016.10 
[2] Wang Tao Peng. A Study on the Training Mode of Wanchen's Order-based Talents [J]. Journal of Beijing Finance and Trade Vocational College. 2014.1

[3] Bai Fei, Research on Cooperative Education Mechanism of Higher Vocational Colleges Based on Cooperative Innovation Platform [J]. Journal of Jiangsu Architectural Vocational Technology .2016 (9): 76-78

[4] Liu Li, Building and Deepening of cooperative education of Private Colleges and Universities under Collaborative Innovation [J]. Human Resources Development. 2015.10
[5] Bai Fei, Wan Yuan. School-enterprise Collaborative Practice Teaching System: Connotation, Path and Key Issues [J]. Modern Education Management .2014 (10): 85-90

[6] Chen Xingwen, Liu Yan, Shao Qiang. Study on the Construction of Diversified Mode of School-enterprise Cooperation and Its Practical Strategy [J]. Journal of Dalian Nationalities University (Social Sciences Edition. 